\title{
Inactivation of Escherichia coli 2-Amino-3-ketobutyrate CoA Ligase by Phenylglyoxal and Identification of an Active-Site Arginine Peptide ${ }^{1}$
}

\author{
Jagat J. Mukherjee ${ }^{2}$ and Eugene E. Dekker ${ }^{3}$ \\ Department of Biological Chemistry, The University of Michigan, Ann Arbor, Michigan 48109-0606
}

Received May 19, 1992, and in revised form July 31, 1992

Treatment of homogeneous preparations of 2-amino3-ketobutyrate CoA ligase from Escherichia coli, a pyridoxal 5'-phosphate-dependent enzyme, with phenylglyoxal, 4-(oxyacetyl)phenoxyacetic acid, 2,3-butanedione, or 1,2-cyclohexanedione results in a time- and concentration-dependent loss of enzymatic activity. Phenylglyoxal in $50 \mathrm{~mm}$ phosphate buffer ( $\mathrm{pH} \mathrm{7.0)}$ is the most effective modifier, causing $>95 \%$ inactivation within 20 min at $25^{\circ} \mathrm{C}$. Controls establish that this inactivation is not due to modifier-induced dissociation or photoinduced nonspecific alteration of the ligase. The substrate, acetyl CoA, or the coenzyme, pyridoxal 5 'phosphate, gives $>\mathbf{5 0} \%$ protection against inactivation. Enzyme partially inactivated by phenylglyoxal has the same $K_{m}$ value for glycine but the $V_{\max }$ decreases in proportion to the observed level of inactivation. Whereas the native apoligase shows good recovery of activity with time in parallel with an increase in 428-nm absorptivity when incubated with pyridoxal 5 '-phosphate, no such effects are seen with the phenylglyoxal-modified apoligase.

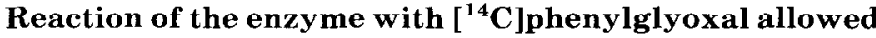
for the isolation of a peptide which, by amino acid composition and sequencing data, was found to correspond to residues $349-378$ in the intact enzyme. These results indicate that arginine residue- 366 and/or residue- 368 in the primary structure of $E$. coli 2 -amino-3-ketobutyrate ligase is at the active site. 1992 Academic Press, Inc.

Threonine metabolism in eukaryotes and prokaryotes has been known to occur via three pathways, one initiated

\footnotetext{
${ }^{1}$ This research was supported by Grant DK-03718 from the National Institutes of Health, United States Public Health Service.

${ }^{2}$ Present address: Department of Biochemistry and Molecular Biology, The University of Manitoba, 770 Bannatyne Avenue, Winnipeg, Manitoba, Canada R3E OW3.

${ }^{3}$ To whom correspondence should be addressed. Fax: (313) 763-4581.
}

by threonine dehydratase, another by threonine aldolase, and a third by threonine dehydrogenase. Recent studies (1-3) have shown that the threonine dehydrogenase-initiated route is probably the most important of the three; it accounts for $87 \%$ of the L-threonine degraded in the liver of normally fed rats (4), it is the only pathway for L-threonine degradation that is detected in chicken liver (5), and it assumes the predominant role in Escherichia coli (6) and other microorganisms (7). Threonine dehydrogenase (EC 1.1.1.103) catalyzes the $\mathrm{NAD}^{+}$-dependent oxidation of L-threonine to 2-amino-3-ketobutyrate (or 2-amino-3-oxobutanoate).

2-Amino-3-oxobutanoate glycine-lyase (CoA-acetylating) (EC 2.3.1.29), also called 2-amino-3-ketobutyrate ligase, aminoacetone synthase, or aminoacetone synthetase, catalyzes the second step in the threonine dehydrogenase-initiated pathway; by this reaction, glycine and acetyl $\mathrm{CoA}$ are formed via a CoA-dependent cleavage of 2-amino-3-ketobutyrate. The conversion of threonine to glycine by the coupled action of these two enzymes accounts for the observation that gly $A$ (serine hydroxymethyltransferase gene) mutants can utilize threonine for growth (8 10). In cells that contain a functional gly $A$ genc, these coupled reactions provide a highly efficient alternate route for serine biosynthesis (6). The genes for threonine dehydrogenase and 2-amino-3-ketobutyrate ligase make up the $t d h$ operon which is located near minute 81 of the $E$. coli genetic map (11). The $t d h$ operon is one among a multigene family that is regulated by L-leucine, mediated by the leucine-responsive regulatory protein (Lrp) ${ }^{4}$ (12-14).

In an earlier paper (15), we reported the purification of 2-amino-3-ketobutyrate ligase to homogeneity from extracts of a mutant of $E$. coli $\mathrm{K}-12$ that we forced to grow

\footnotetext{
${ }^{4}$ Abbreviations used: Lrp, leucine-responsive regulatory protein; PTH, phenylthiohydantoin; PTC, phenylthiocarbamoyl; TFA, trifluoroacetic acid; SDS, sodium dodecyl sulfate.
} 
on L-threonine as sole carbon source; this mutant has constitutively derepressed levels of both threonine dehydrogenase and the ligase. 2-Amino-3-ketobutyrate ligase from $E$. coli is an 84,000-Da protein and consists of two apparently identical subunits. It is a pyridoxal $5^{\prime}$ phosphate-dependent enzyme and is strictly specific for glycine. The primary structure of the $k b l$ (2-amino-3-ketobutyrate $\mathrm{CoA}$ ligase) gene and that of its protein product are known (16).

We are attempting to map active-site amino acid residues in both threonine dehydrogenase $(17-19)$ and this ligase in efforts to elucidate how these two enzymes are tightly coupled or may even form a catalytic complex that allows for efficient passage of the unstable 2-amino-3ketobutyrate to the ligase so that it is cleaved rather than spontaneously decarboxylated. In first studies with the $E$. coli ligase, we isolated and sequenced the active-site peptide containing the lysine residue that forms a Schiff base with pyridoxal 5 -phosphate (20). We now report that an arginine residue (or residues), located in a peptide corresponding to amino acid residues $349-378$ in the native protein, is also a participant in the active site of this enzyme.

\section{MATERIALS AND METHODS}

Enzymes and chemicals. Homogeneous samples of 2-amino-3-ketobutyrate ligase were prepared from extracts of mutant $E$. coli SBD76 cells as reported earlier (15). The purity of all samples was established by polyacrylamide gel electrophoresis, both with and without SDS. The specific activity of enzyme preparations used in these studies was in the range of 2.5 to 2.8 units/mg of protein; a unit of ligase activity is defined as that amount which catalyzed the formation of $1 \mu \mathrm{mol}$ of $\mathrm{CoA} / \mathrm{min}$ at $25^{\circ} \mathrm{C}$. Molar enzyme concentrations are based on the ligase being a homodimer with a relative molecular mass of $84 \mathrm{kDa}$ (15). Staphylococcus aureus V8 endoproteinase was a product of Boehringer Mannheim Biochemicals.

HPLC-grade methanol and acetonitrile were obtained from Burdick and Jackson Laboratories, Inc., whereas phenyl $\left[2-{ }^{14} \mathrm{C}\right]$ glyoxal $(27 \mathrm{mCi}$ ) mmol) was from Research Products International Corp. The following materials were purchased from the companies noted: $5,5^{\prime}$-dithiobis(2nitrobenzoic acid), phenylisothiocyanate, triethylamine, and PTH-amino acid standards from Pierce Chemical Co, acetyl CoA and pyridoxal $\cdot \mathrm{HCl}$ from Sigma Chemical Co; phenylglyoxal, 1,2-cyclohexanedione, and 2,3butanedione from Aldrich Chemical Co.; pyridoxal 5'-phosphate from Nutritional Biochemicals Corp.; TFA from J. T. Baker Chemical Co. 4-(Oxyacetyl)phenoxyacetic acid was kindly provided by Drs. P. .J Duerksen-Hughs and K. D. Wilkinson of Emory University (Atlanta, GA). All other chemicals were of the highest purity commercially available.

The HPLC equipment used to obtain peptide maps and to separate PTH-amino acids has been described before (21).

Assay of ligase activity and inactivation studies with dicarbonyl reagents. 2-Amino-3-ketobutyrate ligase activity was measured spectrophotometrically at $412 \mathrm{~nm}$ as described earlier for Assay I (15). Unless indicated otherwise, inactivation studies were carried out by incubating the enzyme $(12-15 \mu \mathrm{M})$ in the dark with a given dicarbonyl reagent in $50 \mathrm{~mm}$ potassium phosphate buffer $(\mathrm{pH} 7.0)$ at $25^{\circ} \mathrm{C}$. Aliquots $(5-10 \mu \mathrm{l})$ of the reaction mixture were removed at varying time intervals and mixed with $1 \mathrm{ml}$ of the assay mixture, and the increase in absorbance at $412 \mathrm{~nm}$ was monitored.

Protection of ligase activity against inactivation by phenylglyoxal. An aliquot of the enzyme $(12-15 \mu \mathrm{M})$ was first incubated for $30 \mathrm{~min}$ at $25^{\circ} \mathrm{C}$ alone or with acetyl CoA ( $2 \mathrm{mM})$, pyridoxal $5^{\prime}$-phosphate $(3 \mathrm{mM})$, glycine (100 and $200 \mathrm{mM}$ ), or L-threonine $(10$ and $50 \mathrm{mM})$ in $50 \mathrm{~mm}$ potassium phosphate buffer ( $\mathrm{pH} 7.8$ ). Phenylglyoxal (2 mM, final concentration) was then added to the incubation mixture and aliquots were subsequently removed at fixed time points over a period of 20 to $30 \mathrm{~min}$ for assay of ligase activity. Controls consisted of the enzyme alone or the enzyme plus acetyl CoA, pyridoxal 5'-phosphate, glycine, or threonine in the absence of any phenylglyoxal.

Coenzyme-dependent reactivation of native and phenylglyoxal-treated apoligase. Resolution of the holoenzyme was accomplished by dialyzing it against buffer containing $5 \mathrm{~mm}$ hydroxylamine as previously described (15). The apoligase $(20 \mathrm{nmol})$ so prepared was first incubated for $50 \mathrm{~min}$ at $25^{\circ} \mathrm{C}$ in $50 \mathrm{mM}$ potassium phosphate buffer $(\mathrm{pH} 7.0)$ either alone or with $10 \mathrm{mM}$ phenylglyoxal. Pyridoxal 5'-phosphate (100 $\mu \mathrm{M}$, final concentration) was then added to the incubation mixtures and aliquots were subsequently removed at varying time intervals for measuring both ligase activity and absorptivity at $428 \mathrm{~nm}$.

Determination of the nature and number of essential amino acids modified in the ligase. Two methods were used to confirm the usual reaction specificity of phenylglyoxal with amino acid residues in proteins and to determine the number of residues modified; they were comparative amino acid analyses of the native and the phenylglyoxal-inactivated ligase and second, radioactive incorporation measurements with $\left[{ }^{14} \mathrm{C}\right]$ phenylglyoxal.

For amino acid analyses, an aliquot of the enzyme $(0.2 \mathrm{mg})$ was completely inactivated by reaction with $10 \mathrm{mM}$ phenylglyoxal for $40 \mathrm{~min}$ at $25^{\circ} \mathrm{C}$ in $50 \mathrm{mM}$ potassium phosphate buffer ( $\left.\mathrm{pH} 7.0\right)$. An aliquot $(50 \mu \mathrm{l})$ of this reaction mixture and a comparable amount of the native ligase treated in the same manner without phenylglyoxal were hydrolyzed for $24 \mathrm{~h}$ at $110^{\circ} \mathrm{C}$ in $1 \mathrm{ml}$ of $6 \mathrm{~N} \mathrm{HCl}$ containing $20 \mu \mathrm{l}$ of mercaptoacetic acid.

For quantitative radioactive measurements, 2 -amino-3-ketobutyrate ligase $(10.5 \mathrm{nmol})$ was incubated at $25^{\circ} \mathrm{C}$ with $8 \mathrm{mM}$ phenyl $\left[2{ }^{14} \mathrm{C}\right]$ glyoxal ( $\mathrm{sp}$ act $=2175 \mathrm{dpm} / \mathrm{nmol})$ in $50 \mathrm{mM}$ potassium phosphate buffer $(\mathrm{pH}$ $7.0)$; total volume $=0.8 \mathrm{ml}$. At specific times, aliquots $(60 \mu \mathrm{l})$ of the incubation mixture were removed and immediately mixed with $1 \mathrm{ml}$ of ice-cold $10 \%$ trichloroacetic acid, and the mixtures were then centrifuged for $15 \mathrm{~min}$ at $5000 \mathrm{rpm}$. The precipitates were subsequently washed several times with ice-cold $10 \%$ trichloroacetic acid and finally briefly with cold ethanol before they were dried under vacuum. The solid residues remaining were dissolved in a small volume of $0.1 \mathrm{~N} \mathrm{NaCl}$ and the levels of radioactivity in the resultant solutions determined by liquid scintillation counting techniques, making use of a Packard Model 3300 spectrometer and Safety Solve scintillation mixture.

Amino acid analyses. Prior to analysis, enzyme samples were dialyzed exhaustively against glass-redistilled water and then lyophilized. Analyses were usually performed on a Beckman Model 120C automatic amino acid analyzer equipped with a microbore column; half-cystine residues were determined as $S$-sulfocysteine after treating the acid hydrolysate with dithiothreitol and sodium tetrathionate (22). Tryptophan was measured by hydrolyzing the protein with $4 \mathrm{M}$ methanesulfonic acid (23). On occasion, the amino acids present in protein hydrolysates were also determined by HPLC as PTC-amino acid derivatives using the Waters Pico-Tag system (24).

Peptide isolation and sequencing procedures. 2-Amino-3-ketobutyrate ligase $\left(6 \mathrm{mg}\right.$ ) from $E$. coli was incubated at $25^{\circ} \mathrm{C}$ with $10 \mathrm{~mm}$ phenyl[2${ }^{14} \mathrm{Clglyoxal}$ ( $\mathrm{sp}$ act $=1 \mu \mathrm{Ci} / \mu \mathrm{mol}$ ) in $50 \mathrm{~mm}$ potassium phosphate buffer (pH 7.0) for $30 \mathrm{~min}$ after which time less than $3 \%$ of the original ligase activity could be detected. The $\mathrm{pH}$ of the reaction mixture was then decreased to 4.0 by dropwise addition of $2 \mathrm{~N} \mathrm{HCl}$ and the resulting solution dialyzed exhaustively against $50 \mathrm{mM}$ sodium formate buffer ( $\mathrm{pH}$ 4.0). The inactive enzyme adduct was subsequently digested with $S$. aureus V8 endoproteinase ( 25 to $1 \mathrm{~mol}$ ratio, enzyme to protease) at $25^{\circ} \mathrm{C}$ for $24 \mathrm{~h}$. The peptide solution so obtained was first passed through a Gelman Acro LC13 filter and aliquots of the filtrate were then injected directly onto a Waters Novapak $\mathrm{C}_{18}$ HPLC column $(3.9 \mathrm{~mm} \times 15 \mathrm{~cm})$ at room temperature equilibrated with $0.1 \%(\mathrm{v} / \mathrm{v})$ of TFA. Peptides were separated and eluted using TFA/acetonitrile solvent mixtures in 


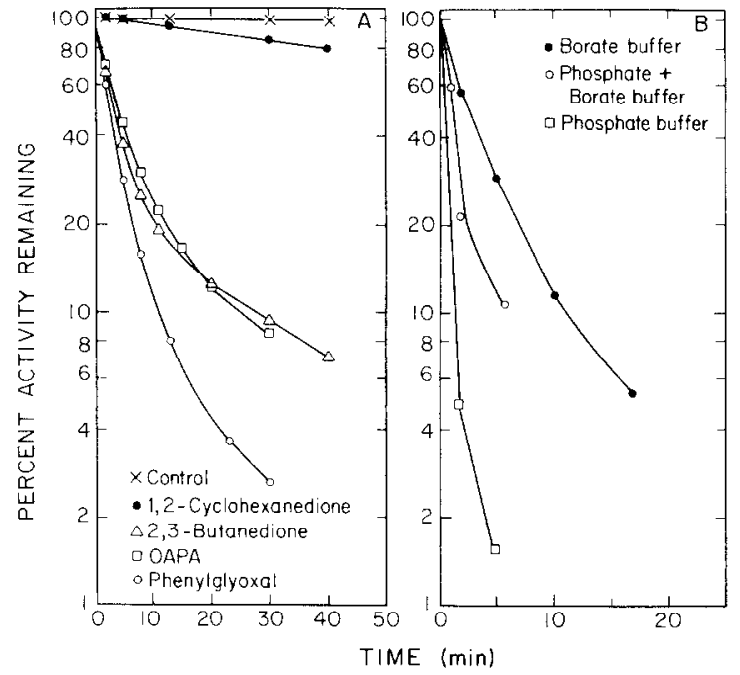

FIG. 1. (A) Effect of various dicarbonyl reagents on $E$. coli 2-amino3 -ketobutyrate ligase activity. The sample of enzyme used was first dialyzed for $8 \mathrm{~h}$ at $4^{\circ} \mathrm{C}$, against $50 \mathrm{mM}$ borate buffer $(\mathrm{pH} 7.8)$. The ligase $(0.2 \mathrm{mg})$ was then incubated at $25^{\circ} \mathrm{C}$ with each reagent $(10 \mathrm{mM})$ indicated in $50 \mathrm{mM}$ borate buffer ( $\mathrm{pH} 7.8)$; final volume, $0.2 \mathrm{ml}$. Aliquots $(10 \mu \mathrm{l})$ were removed at the times indicated, added to cuvettes in a final volume of $1.0 \mathrm{ml}$, and assayed as indicated in the text. OAPA, 4-(oxyacetyl)phenoxyacetic acid. (B) Effect of buffer on ligase inactivation by phenylglyoxal. Enzyme as in (A) was incubated with $10 \mathrm{mM}$ phenylglyoxal in $50 \mathrm{~mm}$ borate buffer (pH 7.8), $50 \mathrm{~mm}$ phosphate plus $50 \mathrm{mM}$ borate buffer ( $\mathrm{pH} 7.8$ ), or $50 \mathrm{~mm}$ phosphate buffer ( $\mathrm{pH} 7.8$ ). Aliquots were removed and assayed as indicated for (A). Controls in (A) and (B) contained no dicarbonyl reagent.

sequence as follows: $0-25 \mathrm{~min}$ linear gradient $(0-25 \%, \mathrm{v} / \mathrm{v})$ of acetonitrile in $0.1 \%$ TFA; $25-75$ min linear gradient $(25-55 \%)$ of acetonitrile in $0.1 \%$ TFA. Fractions $(1 \mathrm{ml})$ were collected and the presence of radioactivity therein was determined by liquid scintillation counting.

Those fractions containing the radioactivity of interest were pooled and further purified by HPLC by passage through a Waters Novapak $\mathrm{C}_{18}$ analytical column using a linear gradient of $28-35 \%(\mathrm{v} / \mathrm{v})$ acetonitrile in $0.1 \%$ TFA over a period of $60 \mathrm{~min}$. The purified, radioactive peptide so obtained was concentrated to dryness and sequenced manually by the thin-film and the partitioning method described by Tarr (25).

\section{RESULTS}

Inactivation studies wilh various dicarbonyl reagents. As is shown in Fig. 1A, incubation of E. coli 2amino-3-ketobutyrate ligase with $10 \mathrm{~mm} 1,2$-cyclohexanedione, 2,3-butanedione, 4-(oxyacetyl)phenyoxyacetic acid, or phenylglyoxal in $50 \mathrm{~mm}$ borate buffer $(\mathrm{pH} 7.8)$ results in a time-dependent loss of enzymatic activity. Phenylglyoxal was found to be the most effective of the modifiers tested, causing $>95 \%$ inactivation within 20 min. Figure 1B compares the rates of inactivation caused by $10 \mathrm{~mm}$ phenylglyoxal in borate as opposed to phosphate buffer; as can be seen, the rate is considerably faster and the extent greater in phosphate buffer. As a consequence, all subsequent inactivation studies were carried out with phenylglyoxal in phosphate buffer.

Loss of 2-amino-3-ketobutyrate ligase activity is also dependent on the concentration of dicarbonyl reagent used; Fig. 2 shows a semilogarithmic plot of the rates of inactivation caused by varying concentrations of phenylglyoxal in $50 \mathrm{~mm}$ potassium phosphate buffer $(\mathrm{pH} 7.0)$. The rates were found not to be linear suggesting that more than one amino acid residue of different reactivity is quite likely being modified during the process of inactivation. The reaction order $(n)$ with respect to the concentration of phenylglyoxal was determined from the slope of a plot of $\log \left(1000 / t_{1 / 2}\right)$ versus the $\log$ of reagent concentration $(\mathrm{mM})$. In this type of plot, a straight line was obtained giving a value of $1.30 \pm 0.10$ (possible slopes within the error bars ranged from 0.74 to 1.88 ).

With E. coli 2-amino-3-ketobutyrate ligase being a homodimeric protein (15), the possibility was considered that the loss of ligase activity on treatment with phenylgloxal might be due to dissociation of the enzyme into its subunits. To test this, a control sample of the enzyme and a sample inactivated $85 \%$ by reaction with phenylglyoxal were first dialyzed extensively against phosphate buffer $(50 \mathrm{mM}, \mathrm{pH} 7.0)$. These samples were then individually applied to and eluted from a column of Sephadex G-100 that had been calibrated previously with proteins of known molecular weight. The two ligase samples were found to have identical elution profiles with the expected relative levels of ligase activity and an elution volume equal to that for a protcin with $M_{r} \cong 84,000$, demonstrating that phenylglyoxal inactivation is not a consequence of subunit dissociation.

It has been reported (26-28) that certain dicarbonyl reagents used for selective modification of arginine residues are photosensitive, causing a loss of enzymatic ac-

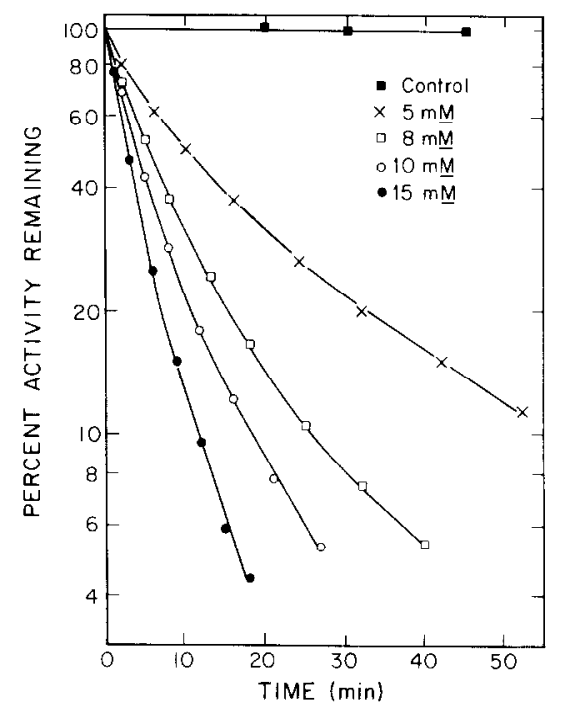

FIG. 2. Inactivation of $E$. coli 2-amino-3-ketobutyrate ligase by varying concentrations of phenylglyoxal. The enzyme $(0.2 \mathrm{mg})$ was incubated in $50 \mathrm{mM}$ potassium phosphate buffer $(\mathrm{pH} 7.0)$ at $25^{\circ} \mathrm{C}$ with the concentrations of phenylglyoxal listed. At the time points plotted, a $10-\mu \mathrm{l}$ aliquot was removed, added to cuvettes in a final volume of $1.0 \mathrm{ml}$, and assayed as indicated in the text. 
tivity because of light-induced alterations in protein structure rather than chemical reaction with an essential residue. This possibility was avoided in the results presented here by routinely carrying out the inactivation reaction in vessels protected from light.

Protective effect of substrates, substrate analogs, or coenzyme against inactivation. The effect that compounds added to the reaction mixture might have on the extent of inactivation caused by phenylglyoxal was tested. Il was found that the presence of either acetyl CoA $(2 \mathrm{mM})$ or pyridoxal 5 -phosphate $(3 \mathrm{mM})$ gives $>50 \%$ protection. When preincubated with the ligase, glycine also provides some protection against inactivation $(\sim 40$ to $60 \%)$ but only when present at high concentrations (100 and 200 $\mathrm{mM}$, respectively). Since the unstable 2-amino-3-ketobutyrate per se is not available for use, threonine was tested as an analog; whereas 10 and $50 \mathrm{mM}$ L-threonine showed good protection ( $\sim 50$ and $75 \%$, respectively) no significant effect was seen when the same concentrations of D-threonine were tested.

Kinetic values of partially inactivated ligase. The enzyme used in these studies was treated with phenylglyoxal in the usual manner except that a limited extent of inactivation was accomplished by adding a threefold excess of L-arginine (relative to the initial concentration of phenylglyoxal) to the reaction mixture after a fixed interval of time. Thereafter, the mixture was dialyzed against $50 \mathrm{mM}$ phosphate buffer $(\mathrm{pH} 7.0)$ to remove excess reagents and dialyzable reaction products. Reaction rates were measured using a constant level of acetyl CoA and varying concentrations of glycine; $K_{m}$ and $V_{\max }$ values were calculated from the experimental data by Lineweaver-Burk plots (29) using a computer-assisted linear least-squares fit. Under the experimental conditions used, native enzyme was determined to have a $K_{m}=12 \mathrm{mM}$ for glycine and a $V_{\max }=2.90 \mu \mathrm{mol}$ of CoA formed $\min ^{-1} \mathrm{mg}^{-1}$, whereas the corresponding values found for inactivated enzyme retaining $58 \%$ of the original level of activity were $13 \mathrm{mM}$ and $1.68 \mu \mathrm{mol} \mathrm{min}{ }^{-1} \mathrm{mg}^{-1}$, respectively.

Reactivation of native and phenylglyoxal-inactivated apoligase by pyridoxal 5'-phosphate. Previous studies showed that the enzymatic activity of the apoenzyme form of $E$. coli 2-amino-3-ketobutyrate ligase could be fully recovered by incubation with pyridoxal 5 -phosphate but not by pyridoxal or pyridoxamine 5 '-phosphate (15). Since pyridoxal 5 '-phosphate gave protection against inactivation of the native ligase by phenylglyoxal, we examined factors affecting reactivation of the apoligase. Under the experimental conditions reported here, good recovery of ligase activity with time in parallel with an increase in 428-nm absorptivity was seen when the native apoenzyme was incubated with pyridoxal 5'-phosphate (Fig. 3). In contrast, when the apoligase was first modified by reaction with $10 \mathrm{mM}$ phenylglyoxal under the usual conditions and then incubated with $100 \mu \mathrm{M}$ pyridoxal 5 -phosphate for

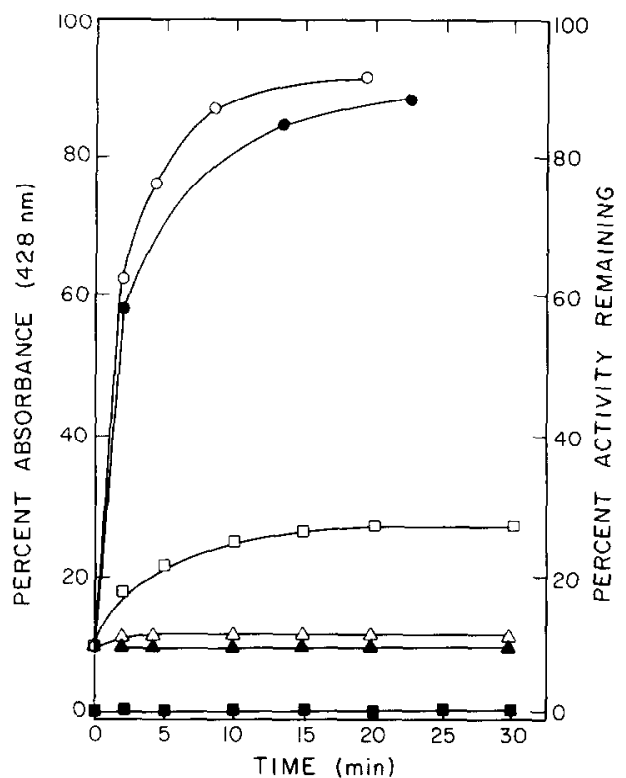

FIG. 3. Time-dependent regeneration of 2-amino-3-ketobutyrate ligase activity and $428-\mathrm{nm}$ absorptivity of native and phenylglyoxal-modified apoenzyme on incubation with pyridoxal 5'-phosphate. Apoligase preparation, its treatment with phenylglyoxal, and subsequent incubation with pyridoxal $5^{\prime}$-phosphate are described under Materials and Methods. Aliquots $(10 \mu 1)$ of the reaction mixture were removed at the times indicated and assayed for both ligase activity (D) and absorptivity at 428 $\mathrm{nm}(\square)$. Controls contained apoligase not reacted with phenylglyoxal but incubated with either pyridoxal 5 -phosphate ( $\bullet$ and $O$, ligase activity and 428-nm absorptivity, respectively) or pyridoxal ( $\Delta$ and $\Delta$, activity and absorptivity, respectively). The absorbance and specific activity of the holoenzyme were taken as $100 \%$.

$30 \mathrm{~min}$, no recovery of enzymatic activity and only a slight increase in absorptivity at $428 \mathrm{~nm}$ was seen. Likewise, incubation of the native apoligase with pyridoxal caused no return of either catalytic activity or unique absorptivity.

In this context, it was also considered whether the observed loss of some or all of the ligase activity on treatment with phenylglyoxal might possibly be due to dissociation of the holoenzyme. To test this, the levels of activity exhibited by pure holoenzyme and the holoenzyme inactivated $70 \%$ by phenylglyoxal were determined after they were first dialyzed against phosphate buffer and then preincubated $\left(30 \mathrm{~min}\right.$ at $\left.4^{\circ} \mathrm{C}\right)$ with varying concentrations (0 to $100 \mu \mathrm{M}$ ) of pyridoxal 5'-phosphate. The added coenzyme had no effect whatever on the level of activity of either enzyme sample, indicating that phenylglyoxal inactivation is not due to holoenzyme dissociation.

Nature and number of essential amino acids modified in the inactivated ligase. Previous studies (30) showed that phenylglyoxal interacts specifically with the guanidinium group of arginine in a stoichiometric relationship of $2 \mathrm{~mol}$ of reagent $/ \mathrm{mol}$ of arginine. To confirm this specificity of reaction with $E$. coli 2 -amino-3-ketobutyrate ligase and to determine the number of residues modified, 
amino acid analyses were carried out on native as well as dione-inactivated ligase. The amino acid composition determined for the native enzyme, showing 26.3 arginine residues per subunit, was in excellent agreement for each residue with that reported earlier (15). In contrast, whereas the content of all of the other amino acid residues was the same for the phenylglyoxal-inactivated enzyme, only 24.8 residues of arginine per subunit were found in this sample. Hence, complete inactivation was associated with the loss of 1.5 arginine residues per ligase subunit.

The correlation between the loss of ligase activity and the incorporation of $\left[{ }^{14} \mathrm{C}\right]$ phenylglyoxal as a function of time is shown in Fig. 4. If it is assumed that the stoichiometry of reaction is as noted earlier, the data again indicate that approximately two arginine residues/ligase subunit are modified in the inactivated enzyme.

Isolation and purification of peptides containing phenylglyoxal-modified residues. S. aureus V8 endoproteinase was used to obtain peptide digests of $E$. coli 2-amino-3ketobutyrate ligase modified by $\left[{ }^{14} \mathrm{C}\right]$ phenylglyoxal. A representative peptide map of a digest separated by HPLC is shown in Fig. 5A. Fractions eluted at 11 to $13 \mathrm{~min}$ contained $88 \%$ of the applied radioactivity with the remaining $12 \%$ found in fractions at 43 to $46 \mathrm{~min}$. We were surprised that when the fractions containing the first radioactive peak were chromatographed a second time on a Novapak $\mathrm{C}_{18}$ column with a different acetonitrile gradient (i.e. $28-35 \%$ acetonitrile in $0.1 \%$ TFA over 0 to 60 $\mathrm{min}$ ), the eluted radioactive peak showed no absorptivity at $214 \mathrm{~nm}$ (data not shown). We therefore took ligase that had been inactivated by reaction with $\left[{ }^{14} \mathrm{C}\right]$ phenylglyoxal but was not digested with the endoproteinase and subjected it directly to HPLC on the Novapak column under the same experimental conditions. Again in this instance,

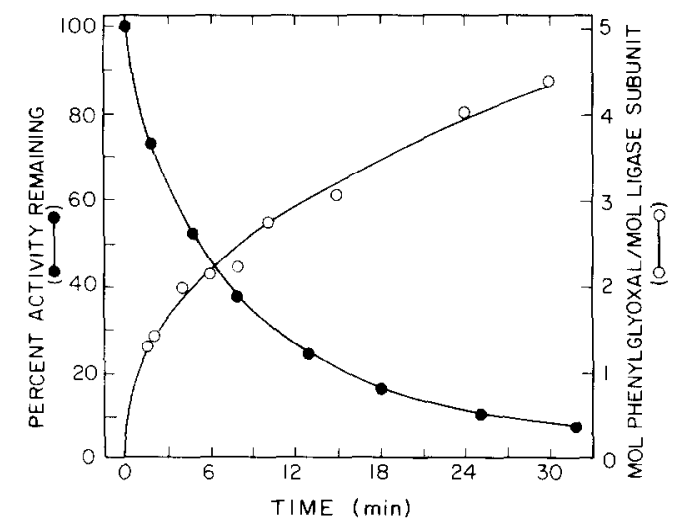

FIG. 4. Correlation of the extent of inactivation of $E$. coli 2-amino3-ketohutyrate ligase activity hy phenylglyoxal with the number of mol of $\left[{ }^{14} \mathrm{C}\right]$ phenylglyoxal bound to the enzyme. The ligase was inactivated by incubating with phenyl $\left[2{ }^{14} \mathrm{C}\right]$ glyoxal. At the times indicated, an aliquot $(10 \mu \mathrm{l})$ was removed for assaying ligase activity and another (60 $\mu \mathrm{l})$ for precipitating, washing, and redissolving the protein before measuring the level of radioactivity present. Experimental details are given under Materials and Methods.

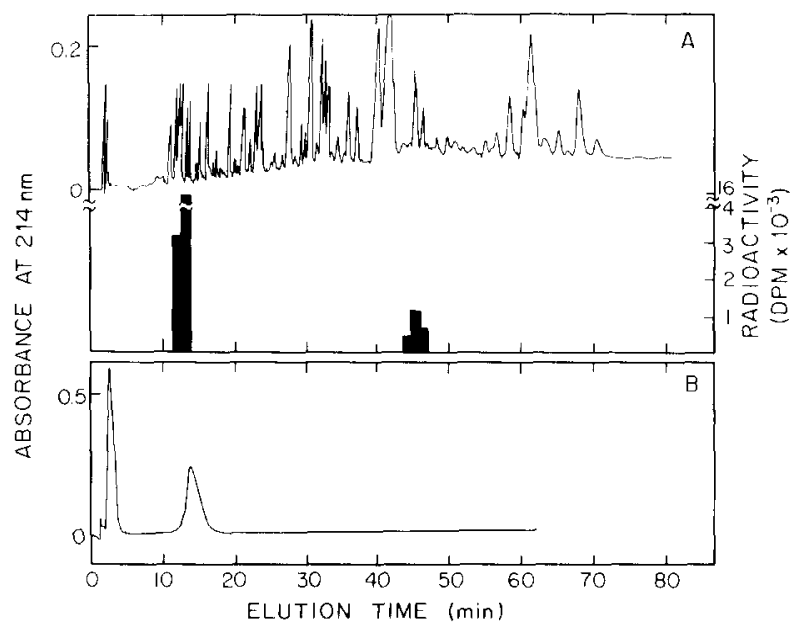

FIG. 5. Peptide maps of $E$. coli 2-amino-3-ketobutyrate ligase after digestion with Staphylococcus aureus V8 endoproteinase. (A) Ligase inactivated approximately $97 \%$ by reaction with phenyl $\left[2{ }^{14} \mathrm{C}\right]$ glyoxal. (B) Rechromatography of the second radioactive peptide eluting at 43 to 46 min in peptide map (A). The solid histograms indicate the amount of radioactivity found in the collected fractions. Experimental details are given under Materials and Methods and in the text.

the major radioactive peak (eluting at 12 to $13 \mathrm{~min}$ containing $80 \%$ of applied radioactivity) showed no 214-nm absorptivity (data not shown). This result suggests that the early-eluting, major radioactive peak seen in Fig. $5 \mathrm{~A}$ is likely due to the presence of free phenylglyoxal which is leached from any bound form of the reagent under HPLC experimental conditions. The second radioactive peak in Fig. $5 \mathrm{~A}$ (eluting at 43 to $46 \mathrm{~min}$ ) was therefore pooled and rechromatographed on the Novapak $\mathrm{C}_{18} \mathrm{col}-$ umn using a linear gradient over $60 \mathrm{~min}$ of $28-35 \%$ acetonitrile in $0.1 \%$ aqueous TFA. As can be seen in Fig. 5B, a fairly broad uv-absorbing peak containing most of the applied radioactivity was eluted between approximately 13 and $15 \mathrm{~min}$. These fractions were pooled and the sample was subjected to amino acid analysis as well as sequence determination. Although the purity of the eluted peak was suspect because of its shape, the very clean PTHamino acid chromatograms we obtained throughout the manual Edman degradation procedure excluded the possibility of this peak being contaminated by other peptides. The broadness of the peak is most likely due to slow leaching during chromatography of free phenylglyoxal from the peptide-dione adduct.

Amino acid composition and sequence determination of the radioactive peptide. The radioactive peptide isolated as shown in Fig. $5 \mathrm{~B}$ was hydrolyzed with $6 \mathrm{~N} \mathrm{HCl}$ containing $1 \%$ phenol and its composition determined by HPLC as PTC-amino acid derivatives using the Waters Pico-Tag system. The results are shown in Table I; when calculated to the nearest whole integer, a total of 30 amino acid residues was found including two arginines. These two residues were detected as $\mathrm{PTC}$-arginine rather than 
TABLE I

Amino Acid Composition of the $\left[{ }^{14} \mathrm{C}\right]$ Phenylglyoxal-Arginine Peptide of E. coli 2-Amino-3-ketobutyrate Ligase

\begin{tabular}{lcc}
\hline Amino acid $^{a}$ & Residue/peptide $^{b}$ & $\begin{array}{c}\text { Residues in enzyme } \\
\text { sequence } 349 \text { to } 378^{c}\end{array}$ \\
\hline Glu/Gln & $3.90(4)$ & 3 \\
Ser & $0.90(1)$ & 1 \\
Gly & $2.73(3)$ & 3 \\
His & $0.82(1)$ & 1 \\
Arg & $2.00(2)$ & 2 \\
Thr & $2.40(2)$ & 3 \\
Ala & $3.50(3)$ & 3 \\
Pro & $2.33(2)$ & 3 \\
Tyr & $1.70(2)$ & 2 \\
Val & $3.30(3)$ & 2 \\
Met & $0.74(1)$ & 2 \\
Ile & $2.60(3)$ & 1 \\
Phe & $1.76(2)$ & 30 \\
Lys & $0.70(1)$ & \\
Total & 30 & \\
\hline
\end{tabular}

${ }^{a}$ Determined by HPLC as PTC-amino acid derivatives using the Waters Pico-Tag system (24).

${ }^{b}$ The first values listed are from amino acid analyses; data are the average of duplicate samples hydrolyzed and analyzed separately. The nearest whole integer numbers are given in parentheses.

${ }^{c}$ From Aronson et al. (16).

PTC-phenylglyoxal-arginine peaks since the Pico-Tag procedure is carried out under highly alkaline conditions. Manually, we were able to determine the sequence of the first 17 amino acid residues of this peptide by the thinfilm and partitioning method of Tarr (25); it had the primary structure Gly-Ile-Tyr-Val-Thr-Gly-Phe-PheTyr-Pro-Val-Val-Pro-Lys-Gly-Gln-Ala. From the known amino acid sequence for $E$. coli 2-amino-3-ketobutyrate ligase, as deduced from DNA sequencing (16), and the known specificity of the V8 endoproteinase for cleaving peptide bonds involving the carboxyl group of glutamic acid, it can be determined that this 17-aminoacid sequence corresponds to residues 349 to 365 in the primary structure of the ligase. Consequently, the complete 30-amino-acid peptide as isolated represents the stretch from residues 349 to 378 in the intact enzyme. The amino acid composition as found for the isolated peptide is consistent with this conclusion.

\section{DISCUSSION}

The primary importance of the threonine dehydrogenase-initiated pathway in threonine metabolism, whereby L-threonine is converted by the two-step, sequential action of threonine dehydrogenase and 2-amino-3-ketobutyrate ligase to 2-amino-3-ketobutyrate and then acetyl CoA plus glycine, has come to the forefront in recent years. The genes for these two enzymes make up the $t d h$ operon. The $t d h$ operon lies within a 3.6 -kb EcoRI fragment lo- cated at coordinate 81.2 of the $E$. coli genetic map (11); the $k b l$ gene is immediately upstream of the $t d h$ gene within the same $E c o$ RI fragment and both genes are transcribed from a common promoter $(6,11,31)$. The operons of a multigene family which includes $t d h$, collectively known as the "leucine regulon," are up- or down-regulated by L-leucine via a leucine-responsive regulatory protein encoded by the $\operatorname{lrp}$ gene. Lrp transcriptionally regulates the operons containing the $i l v l H$, ser $A$, sdaA, oppABCDF, and $t d h$ genes; L-leucine induces the activity of the $t d h$ operon about sevenfold.

One phase of our research is to elucidate the properties and structure/function interrelationships of the two gene products of the $E$. coli $t d h$ operon. Past efforts have led to the isolation of both proteins in homogeneous form, and some of the general properties of each have been described $(3,15)$. So far, we have succeeded in identifying 2 catalytically essential amino acid residues in threonine dehydrogenase, namely, an arginine (19) and a cysteine (18) residue. Other than for identifying lysine 244 as the residue that forms the azomethine (Schiff base) linkage with pyridoxal 5 -phosphate in 2-amino-3-ketobutyrate ligase (20), no other details interrelating structure with catalytic capability are known for this enzyme from $E$. coli. The results presented here establish the presence of an active-site arginine residue (or two) near the C-terminus of this ligase.

While $\alpha$-dicarbonyl compounds occasionally react with residues in proteins other than arginine $(30,32-35)$, they are among the more specific reagents currently available for modification of a specific amino acid. E. coli 2-amino3 -ketobutyrate ligase is rapidly inactivated by 2,3-butanedione and phenylglyoxal; reaction with the less widely utilized reagent, 4-(oxyacetyl)phenoxyacetic acid, which was uniquely useful for us in other studies with 2-keto4-hydroxyglutarate aldolase (36), also effectively inactivates this ligase. Appropriate experimental conditions and/or controls rule out the possibility that the observed loss of ligase activity is due to photo-induced nonspecific alteration of the enzyme, ligand-induced dissociation of the enzyme into its subunits, or ligand-induced dissociation of the coenzyme. Kinetic analyses with the native and partially inactivated ligase show that the $K_{m}$ value for glycine is essentially unchanged whereas $V_{\max }$ for the modified enzyme is correspondingly lower; such effects are consistent with an inactivation process in which active and completely inactivated enzyme molecules are present (37). These kinetic results together with the good level of protection against inactivation observed in the presence of substrates and the coenzyme strongly suggest that the arginine residue(s) identified here is within the active center of the enzyme.

E. coli 2-amino-3-ketobutyrate ligase contains a total of 26 arginine residues/subunit $(15,16)$; of this total, about half are present in the amino acid sequence that makes up the last $\frac{1}{3}$ of the protein molecule at the $\mathrm{C}$-terminal 
end. Comparative amino acid analyses of the native and the phenylglyoxal-inactivated enzyme and data correlating the loss of ligase activity with the number of moles of $\left[{ }^{14} \mathrm{C}\right]$ phenylglyoxal incorporated indicate a stoichiometry of approximately 2 arginine residues modified/ subunit in the completely inactivated enzyme. The radioactive peptide isolated by HPLC after protease digestion contained 2 arginines, namely, residues 366 and 368 (the C-terminus is alanine-398). Whether both of these arginine residues are indeed labeled by reaction with $\left[{ }^{14} \mathrm{C}\right]$ phenylglyoxal could not be determined in this study and whether both are participants in the active site of this enzyme awaits the development of an alternate experimental technique. The long length (30 amino acid residues) of this peptide precluded manual sequencing of it in its entirety, and even if this had been possible the results would probably not be definitive since manual Edman amino acid sequencing techniques involve highly basic conditions which regenerate free phenylglyoxal from the phenylglyoxal-arginine adduct. Selective changing of these 2 arginine residues separately and together by sitedirected mutagenesis would probably be most informative.

\section{REFERENCES}

1. Dale, R. A. (1978) Biochim. Biophys. Acta 544, 496-503.

2. Komatsubara, S., Murata, K., Kisumi, M., and Chibata, I. (1978) J. Bacteriol. 135, 318-323.

3. Boylan, S. A., and Dekker, E. E. (1981) J. Biol. Chem. 256, 18091815.

4. Bird, M. I., and Nunn, P. B. (1983) Biochem. J. 214, 687-694.

5. Aoyama, Y., and Motokawa, Y. (1981) J. Biol. Chem. 256, 1236712373

6. Ravnikar, P. D., and Somerville, R. L. (1987) J. Bacteriol. 169, 2611-2617.

7. Marcini, M. A., and Castric, P. A. (1989) Curr. Microbiol. 18, 105108.

8. Newman, E. B., Kapoor, V., and Potter, R. (1976) J. Bacteriol. 126, $1245-1249$

9. Fraser, J., and Newman, E. B. (1975) J. Bacteriol. 122, 810-817.

10. Van Lenten, E. J., and Simmonds, S. (1965) J. Biol. Chem. 240, $3361-3371$

11. Aronson, B. D., Somerville, R. L., Epperly, B. R., and Dekker, E. E. (1989) J. Biol. Chem. 264, 5226-5232.
12. Tuan, L. R., D'ari, R., and Newman, E. B. (1990) J. Bacleriol. 172, 4529-4535.

13. Rex, J. H., Aronson, R. D., and Somerville, R. L. (1991) J. Bacteriol $173,5944-5953$.

14. Haney, S. A., Platko, J. V., Oxender, D. L., and Calvo, J. M. (1992) J. Bacteriol. 174, 108-115.

15. Mukherjee, J. J., and Dekker, E. E. (1987) J. Biol. Chem. 262, 14441-14447.

16. Aronson, B. D., Ravnikar, P. D., and Somerville, R. L. (1988) Nucleic Acids Res. 16, 3586.

17. Craig, P. A., and Dekker, E. E. (1990) Biochim. Biophys. Acta 1037, 30-38.

18. Epperly, B. R., and Dekker, E. E. (1991) J. Biol. Chem 266, 60866092.

19. Epperly, B. R., and Dekker, E. E. (1989) J. Biol. Chem. 264, 1829618301.

20. Mukherjee, J. J., and Dekker, E. E. (1990) Biochim. Biophys. Acta 1037, 24-29.

21. Vlahos, C. J., and Dekker, E. E. (1986) J. Biol. Chem. 261, 1104911055 .

22. Inglis, A. S., and Liu, T.-Y. (1970) J. Biol. Chem. 245, 112-116.

23. Inglis, A. S., McMahon, D. T. W., Koxburgh, C. M., and Takayanagi, H. (1976) Anal. Biochem. 72, 86-94.

24. Bidlingmeyer, B. A., Cohen, S. A., and Tarvin, T. L. (1984) J. Chromatogr. 336, 93-104.

25. Tarr, G. E. (1986) in Microcharacterization of Polypeptides: A Practical Manual (Shively, J. E., Ed.), pp. 155-194, Humana, Clifton, NJ.

26. Riordan, J. F. (1979) Mol. Cell. Biochem. 26, 71-92.

27. Mäkinen, K. K., and Mäkinen, P.-L. (1982) Biosci. Rep. 2, 169175.

28. Mäkinen, K. K., Mäkinen, P.-L., Wilkes, S. H., Bayliss, M. E., and Prescott, J. M. (1982) J. Biol. Chem. 257, 1765-1772.

29. Lineweaver, H., and Burk, D. (1934) J. Am. Chem. Soc. 56, 658661.

30. Takahashi, K. (1968) J. Biol. Chem. 243, 6171-6179.

31. Ravnikar, P. D., and Somerville, R. L. (1987) J. Bacteriol. 169, 4716-4721.

32. Liu, W.-H., Feinstein, G., Osuga, D. T., Haynes, R., and Feeney, R. E. (1968) Biochemistry 7, 2886-2892.

33. Yankeelov, J. A., Jr. (1972) Methods Enzymol. 25, 566-579.

34. Eun, H.-M., and Miles, E. W. (1984) Biochemistry 23, 6484-6491.

35. Cheng, K.-C., and Nowak, T. (1989) J. Biol. Chem. 264, 3317-3324.

36. Vlahos, C. J., and Dekker, E. E. (1988) J. Biol. Chem. 263, $11683-$ 11691.

37. Ferti, C., Curti, B., Simonetta, M. P., Ronchi, S., Galliano, M., and Minchiotti, L. (1981) Eur. I. Binchem. 119, 553-557. 